\title{
Stage I Prostate Cancer AJCC v6
}

National Cancer Institute

\section{Source}

National Cancer Institute. Stage I Prostate Cancer A/CC v6. NCI Thesaurus. Code C7555.

Stage I includes: T1, N0, M0, G1. T1: Tumor invades subepithelial connective tissue. N0:

No regional metastasis. M0: No distant metastasis. G1: Well differentiated (slight

anaplasia) (Gleason 2-4). (AJCC 6th ed.) - 2003 